\title{
Experimental broodstock diets as partial fresh food substitutes in white shrimp Litopenaeus vannamei B.
}

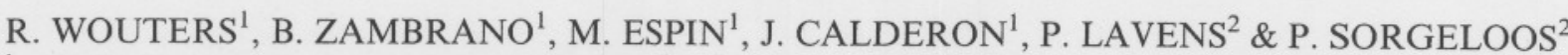 \\ 'CENAIM-ESPOL Foundation, Guayaquil, Ecuador; ${ }^{2}$ Laboratory of Aquaculture \& Artemia Reference Center, Ghent University, \\ Gent, Belgium
}

\begin{abstract}
In the first experiment, conducted in a research facility, Litopenaeus vannamei broodstock were fed either a $100 \%$ fresh food control treatment (FRE, consisting of frozen squid, oyster, mussel and enriched Artemia biomass in a 2.3:1.4:1.3:1 dry matter ratio) or one of the two treatments in which $50 \%$ [dry matter (DM)] of the fresh food was substituted with experimental artificial diets: a dry diet based on freeze-dried Artemia biomass (ART) and a control dry diet $(\mathrm{CON})$. In the second experiment, conducted in a commercial hatchery, shrimp broodstock were fed either a fresh ration (FRE, consisting of frozen squid, polychaetes and enriched Artemia biomass in a 2.5:1.5:1 DM ratio) or the same experimental artificial diets (ART and CON) replacing $50 \%$ of the DM by elimination of polychaetes and Artemia biomass. In experiment 1 treatments $\mathrm{CON}$ and ART produced better results $(P=0.05)$ than treatment FRE in terms of spawn performance and egg production per female. In experiment 2 no differences were detected among treatments FRE and CON whereas treatment ART performed better $(P=0.05)$ in terms of spawning, egg production per female and spermatophore quality. Broodstock survival and offspring quality did not differ between treatments in either experiment.
\end{abstract}

KEY WORDS: diets, maturation, nutrition, reproduction, shrimp

Received 23 February 2001, accepted 8 November 2001

Correspondence: $R$. Wouters, Laboratory of Aquaculture \& Artemia Reference Center, Ghent University, Rozier 44, B-9000 Gent, Belgium. E-mail: r.wouters@inve.be

\section{Introduction}

Diet is a factor that influences the reproductive performance and offspring quality of penaeid shrimp broodstock (Harrison 1990). In captive conditions, hatchery managers rely on fresh or fresh-frozen food to ensure optimal reproductive output. Fresh food items are generally wild-caught marine organisms selected according to their availability and fed in mixed ratios to increase the chances of meeting the nutritional requirements of the broodstock shrimp (Bray \& Lawrence 1992; Pinon 2000). The most commonly used fresh food organisms are molluscs (squid, clam, mussel), crustaceans (shrimp, Artemia biomass) and marine polychaete worms (bloodworms) (Harrison 1997). The disadvantages of such fresh food organisms include high costs, fluctuation in availability, inconsistent nutritional value, need for frozen storage, water fouling, lack of potential for improvement, and increased risk of transmission of pathogenic bacteria and viruses (Harrison 1990, 1997).

Artificial dry diets are the most logical choice to solve the problems associated with fresh food. They have a generally stable cost, constant availability, constant and controlled nutritional value, long shelf-life, easy use and low risk of contamination. In addition, essential nutrients, hormones and therapeutics can easily be added. Unfortunately, artificial dry diets have not performed as well as fresh diets. Consequently, in commercial hatcheries in the western hemisphere only around $16 \%$ of the total feeding regime is constituted by an artificial broodstock diet (Wouters et al. 2000). The development of suitably performing artificial dry diets for shrimp broodstock is thus a research priority.

The present study evaluates the effect on wild white shrimp Litopenaeus vannamei $\mathrm{B}$. of $50 \%$ fresh food substitution with two experimental artificial diets in terms of reproductive performance, spermatophore quality and offspring quality.

A previous study (Wouters et al. 1999) demonstrated that supplementation of a fresh food broodstock diet with 
fresh-frozen Artemia biomass improved $L$. vannamei reproductive output and larval quality. Spawners that received Artemia biomass showed higher survival percentages and better ovarian maturation, spawning and repeated spawning performance. Moreover, the spawners receiving Artemia biomass produced better offspring in terms of egg hatch, larval survival and larval length. Artemia biomass is collected from salt lakes, salinas, man-managed pond productions and intensive culture systems for use in shrimp and fish hatcheries (Lavens \& Sorgeloos 1996). With the increasing threat of viral pathogens worldwide, seriously affecting hatchery and grow-out production in the shrimp industry, the need emerges for improved hygiene and strict biosecurity (Browdy 1998). This includes the use of dry feeds that are free of pathogens. The process of making a dry extruded broodstock diet - preconditioning, extrusion and drying (Harper 1988) - will indeed eliminate viable bacteria and viruses (Chris Dinneweth, INVE TECHNOLOGIES N.V., Baasrode, Belgium) because of the heat treatment (Chang et al. 1998) and the extraction of water. Several studies in Thailand showed that the processing temperatures and drying used for preparation of shrimp head meal and the temperatures for pellet production are sufficient to inactivate any white spot virus or yellow head virus that might be present (Flegel 2001). Although the use of fresh-frozen Artemia biomass has not been associated with an increased risk of infections, hatchery managers prefer dry diets to natural ingredients. Processing this Artemia biomass into a meal and incorporating it into an extruded broodstock diet could help hatchery managers to reduce the risk of transmitting pathogens to the shrimp broodstock (Harrison 1990, 1997). The question remains if the beneficial effects of frozen Artemia biomass on shrimpreproductive performance are maintained after these processing steps. It was as such an additional aim of this study to verify this.

\section{Materials and methods}

\section{Experiment 1: Research facility}

Animals Wild $L$. vannamei were caught by artisanal fishermen on the Ecuadorian coast between Ayangue and Olón (Guayas Province) and brought to the CENAIM research facilities in San Pedro. Upon arrival animals were treated against filamentous bacteria, fungal and protozoan infections with formalin according to the method described by Simon (1982) and kept in maturation tanks. Once enough animals were available for the experimental work, the animals were acclimated to the experimental conditions for a period of 2 weeks during which they were fed on the different experimental diets described below.

Experimental conditions Unilateral eye-stalk ablation was applied to the females by cutting and pinching, and the intact eye-stalk was marked with numbered rings to allow individual monitoring. Each tank was stocked with 40 females and 45 males. Culture conditions, daily routine and monitoring of evaluation parameters related to broodstock performance and offspring quality were as described by Wouters et al. (1999). Oval-shaped $\left(5 \times 3 \mathrm{~m} ; 19.6 \mathrm{~m}^{2}\right)$ black fibreglass maturation tanks were used, supplied with sand-filtered and UV-treated sea water from a reservoir tank. Water was exchanged at a rate of $250 \%$ daily to keep water quality optimal and similar in all tanks. Water temperature in the maturation tanks was $29.4 \pm 0.3{ }^{\circ} \mathrm{C}$, salinity $32.7 \pm 0.8 \mathrm{~g} \mathrm{~L}^{-1}$, and $\mathrm{pH} 8.4 \pm 0.1$. A timercontrolled, inverted photoperiod of $14 \mathrm{~h}$ light:10 h dark was adopted, with gradual transition between light and dark hours. Mated females were transferred to individual 300-L black spawning tanks, and from each spawn the eggs were hatched out in 20 -L buckets. Nauplii were collected after phototactic selection and stocked in 1-L bottles at a density of $100 \mathrm{~L}^{-1}$ and a temperature of $29^{\circ} \mathrm{C}$ until metamorphosis to zoea $1(\mathrm{Zl})$. The hatching percentage was estimated by concentrating the viable nauplii in a $10 \mathrm{~L}$ bucket and counting five subsamples. The percentage of egg fertilization was determined by the presence of a double membrane and/or embryonic development. Zoea 1 length was measured with a profile projector on samples of 30 zoea each. Spermatophore quality was based on sperm count and spermatophore weight (according Alfaro \& Lozano 1993).

Dietary treatments During the acclimation period a feeding rate of $2.1 \%$ day $^{-1}$ dry matter (DM) of the total shrimp biomass was applied. After ablation the feeding rate was increased to $3.15 \%$ day $^{-1} \mathrm{DM}$. One dietary treatment consisted of a feeding regime of frozen fresh food containing squid, oyster, mussel and enriched Artemia biomass in a 2.3:1.4:1.3:1 ratio (DM) and is denominated 'FRE'. The enriched Artemia biomass was ongrown Artemia harvested from salt evaporation ponds at San Francisco Bay (USA) and enriched with menhaden fish oil and astaxanthin according to the standard bio-encapsulation method used by San Francisco Bay Brand Inc (CA, USA). In two additional dietary treatments, $50 \% \mathrm{DM}$ of the fresh food was substituted with experimental dry diets. In these latter 
treatments, the enriched Artemia was completely substituted, while squid, oyster and mussel were fed in reduced quantities. The two experimental dry diets were formulated to be isolipidic and iso-nitrogenous (Table 1): diet CON (control diet), and diet ART (diet containing 33\% Artemia meal).

The Artemia meal was also a SFBB product provided to us by INVE Americas Inc (Salt Lake City, UT, USA). This product was freeze-dried and ground through a $500-\mu \mathrm{m}$ screen. All the ingredients (Table 1) were mixed with $45 \%$ $(\mathrm{w} / \mathrm{w})$ warm water $\left(100^{\circ} \mathrm{C}\right)$ and the resulting dough was heated and pressed through the 3-mm orifice die of a semi-

Table 1 Composition of the artificial broodstock diets fed to Litopenaeus vannamei (\% dry matter) in experiments 1 and 2

\begin{tabular}{|c|c|c|c|}
\hline & \multirow{2}{*}{$\begin{array}{l}\text { CON } \\
\text { Experiment } 1 \& 2\end{array}$} & \multicolumn{2}{|l|}{ ART } \\
\hline & & Experiment 1 & Experiment 2 \\
\hline \multicolumn{4}{|l|}{ Ingredients } \\
\hline Squid meal' & 35 & 19 & 28 \\
\hline Artemia meal $^{2}$ & 0 & 33 & 20 \\
\hline Fish meal $^{3}$ & 15.91 & 7.98 & 9.79 \\
\hline Krill meal $^{4}$ & 5 & 3 & 3 \\
\hline Fish hydrolisates ${ }^{4}$ & 5 & 3 & 3 \\
\hline Wheat gluten 5 & 6 & 6 & 6 \\
\hline Soybean meal ${ }^{5}$ & 5 & 5 & 5 \\
\hline Wheat meal ${ }^{5}$ & 4 & 4 & 4 \\
\hline Corn starch ${ }^{6}$ & 14.535 & 9.565 & 11.755 \\
\hline Fish oil ${ }^{7}$ & 1.16 & 1.06 & 1.06 \\
\hline Egg lecithin ${ }^{8}$ & 1 & 1 & 1 \\
\hline Cholesterol $^{9}$ & 0.5 & 0.5 & 0.5 \\
\hline Vitamin mix ${ }^{10}$ & 2.28 & 2.28 & 2.28 \\
\hline Mineral mix ${ }^{11}$ & 2.1 & 2.1 & 2.1 \\
\hline Atractant ${ }^{1}$ & 1.5 & 1.5 & 1.5 \\
\hline Binder ${ }^{12}$ & 1 & 1 & 1 \\
\hline Etoxiquin $^{12}$ & 0.015 & 0.015 & 0.015 \\
\hline \multicolumn{4}{|c|}{ Formulated composition } \\
\hline Moisture & 6 & 6 & 6. \\
\hline Protein & 52 & 52 & 52 \\
\hline Lipid & 10.5 & 10.5 & 10.5 \\
\hline
\end{tabular}

1 Rieber \& Son, Bergen, Norway,

${ }^{2}$ Inve Americas Inc., Salt Lake City, UT, USA.

${ }^{3}$ CIPSSA, Puerto Montt, Peru.

${ }^{4}$ Profish SA, Santiago, Chile.

${ }^{5}$ Alimentsa, Guayaquil, Ecuador.

${ }^{6}$ Sumesa, Guayaquil, Ecuador.

${ }^{7}$ Pronova Biocare, Oslo, Norway.

${ }^{8}$ Lucas Meyer, Hamburg, Germany

${ }^{9}$ Sigma, St. Louis, MO, USA.

${ }^{10}$ Vitamin mix ( $\mathrm{mg} \mathrm{kg}^{-1}$ diet): ascorbic acid, 1000; biotin, 5; Ca pantothenate, 500; calciferol (D3), 12.7; choline, 3500; cyanocobalamine $\left(B_{12}\right)$, 0.3; folic acid, 15; inositol, 4000; menadione (K3), 40; niacine, 750; p-amino benzoic acid, 100; pyridoxine $\mathrm{HCl}, 120$; riboflavin $\left(B_{12}\right), 200$; thiamine, 120; vitamin A palmitate, 67; $\alpha$-tocopherol, 400 .

"Mineral mix ( $\mathrm{mg} \mathrm{kg}^{-1}$ diet): cobalt chloride, 0.249; copper sulphate, 7.7; Fe citrate, $624 ; \mathrm{KH}_{2} \mathrm{PO}_{4}, 7998 ; \mathrm{KIO}_{3}, 0.747$; manganese sulphate, 40 ; sodium phosphate, 6258 ; sodium selenate, 0.249 , zinc sulphate, 324 .

${ }^{12}$ Nutri-Ad International, Kasterlee, Belgium. industrial meat grinder. All holes but one of the die were blocked to increase pressure. The strands were dried in a ventilated oven at $60^{\circ} \mathrm{C}$ for $2 \mathrm{~h}$ and kept in sealed nitrogenflushed plastic bags at $-20^{\circ} \mathrm{C}$ until use. Each treatment was fed to a single broodstock tank for 70 days.

\section{Experiment 2: Commercial facility}

Animals Wild male $L$. vannamei were caught near San Pablo (Guayas Province, Ecuador) and brought to the commercial hatchery facilities of Granjas Marinas (El Rosario S.A) in Barandúa. Wild female $L$. vannamei were caught in the Esmeraldas Province and transported to Barandúa by truck, with animals placed in individual nets in insulated tanks with oxygenated and cooled sea water. These animals were kept in rectangular cement tanks for approximately 1 week before eyestalk-ablation and transfer to the maturation tanks.

Culture conditions Female spawners were ablated and ringed as described in experiment 1 . The culture conditions in this test were those routinely used by Granjas Marinas: round 7 ton tanks made of fibreglass, 50 females and 50 males per tank, $300 \%$ daily water exchange with sea water of approximately $29^{\circ} \mathrm{C}$, two air stone diffusers per tank, natural photoperiod. Tank bottoms were siphoned once daily. Gravid females were sourced in the evening and transferred to individual spawning tanks. Upon spawning, eggs were concentrated in harvesting buckets and subsamples were taken for egg counts and further estimation of offspring quality according to the method described in experiment 1 . As broodstock replacement is a continuous process in commercial hatchery applications, every newly introduced female was marked and the monitoring of its reproductive performance started after 2 weeks, over a period of 50 days. In total, 107 females were monitored in each treatment. Each treatment was fed to a broodstock tank for 80 days.

Dietary treatments A feeding rate of approximately $4 \%$ day ${ }^{1} \mathrm{DM}$ was applied in all treatments. One dietary treatment was the normal feeding regime of this hatchery (FRE) and consisted of frozen fresh squid, polychaetes from Maine, USA (Glycera dibranchiata) and enriched Artemia biomass in a 2.5:1.5:1 ratio (DM).

As in experiment $1,50 \% \mathrm{DM}$ of the fresh food was replaced with experimental artificial diets CON and ART. In these treatments, the polychaetes and the enriched Artemia were substituted completely, while squid was fed in the same quantity as in the FRE treatment. Formulation and preparation of the artificial diets were the same as in experiment 1 , 
except that diet ART contained 20\% DM Artemia meal instead of $33 \%$ (Table 1).

\section{Statistical analyses}

Because of system limitations in the experimental set-up, each dietary treatment was tested in one tank without replication. Individually tagged animals or spawns were taken as treatment replicates for statistical analyses. This is the most commonly used statistical procedure applied in shrimp reproduction trials (e.g. Browdy et al. 1989; Bray et al. 1990; Robertson et al. 1991; Menasveta et al. 1994; Xu et al. 1994; Cahu et al. 1995; Cavalli et al. 1997; Naessens et al. 1997; Wyban et al. 1997; Wouters et al. 1999). Possible effects caused by individual variation among experimental animals were reduced by randomly stocking the tanks and previous research has demonstrated that between-tank variability is minor (Luis Gómez, CENAIM-ESPOL Foundation, unpublished data). Infertile spawns were not considered. When necessary, data expressed in percentage or fractions were asin $\sqrt{ }$ transformed to obtain normal distributions, although unadjusted means are presented. One-way ANOva (Mead et al. 1993) was applied for statistical analysis (STATISTICA, Statsoft). An ANCOva was applied in experiment 2 for the number of eggs produced per female, with number of spawns as covariate. Chi-square (Mead et al.
1993) was used for evaluating the number of spawns, the number of females with at least one spawning event, and the number of females with repeat spawn performance. Distribution-free parameters were not analysed statistically. To allow statistical processing of survival data, each female was assigned a calculated percentage value, termed 'useful lifetime', which corresponds to the number of days survived relative to the total number of days of the experiment (postablation). Reference to significant differences are at the $5 \%$ level.

\section{Results}

\section{Female performance}

The results of experiments 1 and 2 are summarized in Tables 2 and 3, respectively. Useful lifetime percentages were low in both experiments and did not differ significantly among treatments. The daily maturation frequency was significantly higher in treatment CON than in the remaining treatments (only evaluated in experiment 1 ). In experiment 1 , the spawn frequency and the total number of spawns were higher in the treatments that received artificial diets (CON and ART) as compared with treatment FRE. This relation was also held true with significant differences for repeat spawn performance. The number of eggs produced per

Table 2 Reproductive performance of females, spermatophore quality and offspring quality of Litopenaeus vannamei shrimp in experiment 1 (research facility) as a function of dietary treatment. Mean \pm SD are presented

\begin{tabular}{|c|c|c|c|c|c|c|}
\hline & \multicolumn{6}{|c|}{ Dietary treatments } \\
\hline & FRE & $n$ & CON & $n$ & ART & $n$ \\
\hline \multicolumn{7}{|l|}{ Female performance } \\
\hline Useful lifetime (\%) & $49.0 \pm 16.6^{\mathrm{a}}$ & 40 & $46.0 \pm 16.9^{a}$ & 40 & $42.1 \pm 20.7^{a}$ & 40 \\
\hline Maturation per female per day & $0.114 \pm 0.051^{\mathrm{a}}$ & 57 & $0.142 \pm 0.064^{b}$ & 57 & $0.121 \pm 0.059^{a}$ & 57 \\
\hline Spawns per day per female ${ }^{1}$ & $0.021 \pm 0.012$ & 40 & $0.043 \pm 0.023$ & 40 & $0.040 \pm 0.025$ & 40 \\
\hline Total spawns & 22 & & 60 & & 50 & \\
\hline No. of females with $\geq 1$ spawn & $18^{\mathrm{a}}$ & & $26^{\mathrm{a}}$ & & $23^{\mathrm{a}}$ & \\
\hline No. of females with $\geq 2$ spawns & $3^{\mathrm{a}}$ & & $17^{b}$ & & $14^{b}$ & \\
\hline Fecundity (eggs per spawn $\times 10^{3}$ ) & $181.6 \pm 76.0^{\mathrm{a}}$ & 22 & $213.5 \pm 67.8^{\mathrm{a}}$ & 60 & $230.8 \pm 80.1^{a}$ & 50 \\
\hline Eggs per female & $226.8 \pm 132.8^{a}$ & 40 & $480.5 \pm 296.7^{b}$ & 40 & $501.7 \pm 449.2^{b}$ & 40 \\
\hline \multicolumn{7}{|l|}{ Spermatophore quality } \\
\hline Sperm count $\left(10^{6}\right)$ & $17.38 \pm 12.89^{a}$ & 37 & $15.57 \pm 8.84^{\mathrm{a}}$ & 28 & $21.29 \pm 14.82^{\mathrm{a}}$ & 36 \\
\hline Spermatophore weight (g) & $0.068 \pm 0.022^{a}$ & 37 & $0.074 \pm 0.023^{a}$ & 28 & $0.076 \pm 0.026^{\mathrm{a}}$ & 36 \\
\hline \multicolumn{7}{|l|}{ Offspring quality } \\
\hline Egg diameter (mm) & $0.270 \pm 0.003^{\mathrm{a}}$ & 22 & $0.271 \pm 0.006^{a}$ & 60 & $0.271 \pm 0.005^{a}$ & 50 \\
\hline Egg fertilization (\%) & $51.6 \pm 48.3^{a}$ & 22 & $52.6 \pm 47.7^{a}$ & 60 & $69.2 \pm 43.6^{a}$ & 50 \\
\hline Hatch $(\%)$ & $39.5 \pm 29.9^{a}$ & 22 & $38.4 \pm 32.6^{a}$ & 60 & $52.9 \pm 29.3^{a}$ & 50 \\
\hline Deformed nauplii (\%) ${ }^{1}$ & $3.8 \pm 8.0$ & 18 & $3.3 \pm 5.1$ & 54 & $5.1 \pm 6.6$ & 45 \\
\hline Larval survival $(\%)^{1}$ & $56.4 \pm 35.3$ & 18 & $66.8 \pm 28.4$ & 54 & $67.1 \pm 24.0$ & 45 \\
\hline Zoea length $(\mu \mathrm{m})$ & $908.6 \pm 84.6^{\mathrm{a}}$ & 18 & $901.9 \pm 54.4^{\mathrm{a}}$ & 54 & $903.6 \pm 43.9^{\mathrm{a}}$ & 45 \\
\hline
\end{tabular}

'Distribution-free data were obtained, for which no statistical analysis was applied.

Means with different superscripts in the same row are significantly different $(P \leq 0.05)$. 
Table 3 Reproductive performance of female, spermatophore quality and offspring quality of Litopenaeus vannamei shrimp in experiment 2 (commercial facility) as a function of dietary treatment. Means \pm stdev are presented

\begin{tabular}{|c|c|c|c|c|c|c|}
\hline & \multicolumn{6}{|c|}{ Dietary treatments } \\
\hline & FRE & $n$ & CON & $n$ & ART & $n$ \\
\hline \multicolumn{7}{|l|}{ Female performance } \\
\hline Useful lifetime $(\%)^{1}$ & $40.5 \pm 42.4$ & 107 & $44.2 \pm 43.4$ & 107 & $46.7 \pm 41.2$ & 107 \\
\hline Spawns per day per female ${ }^{1}$ & $0.057 \pm 0.437$ & 107 & $0.040 \pm 0.189$ & 107 & $0.051 \pm 0.227$ & 107 \\
\hline Total spawns & 36 & & 39 & & 53 & \\
\hline No. of females with $\geq 1$ spawn & $25^{a}$ & & $25^{a}$ & & $28^{a}$ & \\
\hline No. of females with $\geq 2$ spawns & $8^{\mathrm{a}}$ & & $7^{a}$ & & $17^{b}$ & \\
\hline Fecundity (Eggs per spawn $\times 10^{3}$ ) & $195.9 \pm 89.4^{a}$ & 36 & $192.2 \pm 88.3^{a}$ & 39 & $231.2 \pm 109.6^{\mathrm{a}}$ & 53 \\
\hline Eggs per female & $282.1 \pm 187.5^{a}$ & 107 & $293.2 \pm 211.8^{\mathrm{ab}}$ & 107 & $452.2 \pm 200.4^{b}$ & 107 \\
\hline \multicolumn{7}{|l|}{ Spermatophore quality } \\
\hline Sperm count $\left(10^{6}\right)$ & $6.23 \pm 5.69^{a}$ & 20 & $7.72 \pm 4.16^{\mathrm{a}}$ & 20 & $12.02 \pm 6.24^{b}$ & 20 \\
\hline Spermatophore weight (g) & $0.0490 \pm 0.148^{\mathrm{a}}$ & 20 & $0.0461 \pm 0.206^{\mathrm{a}}$ & 20 & $0.0768 \pm 0.226^{b}$ & 20 \\
\hline \multicolumn{7}{|l|}{ Offspring quality } \\
\hline Egg fertilization (\%) & $75.2 \pm 30.6^{\mathrm{a}}$ & 36 & $75.9 \pm 27.0^{\mathrm{a}}$ & 39 & $83.2 \pm 24.1^{a}$ & 53 \\
\hline Hatch (\%) & $72.5 \pm 33.1^{a}$ & 36 & $74.7 \pm 27.5^{\mathrm{a}}$ & 39 & $81.1 \pm 25.7^{\mathrm{a}}$ & 53 \\
\hline Deformed nauplii $(\%)^{1}$ & $0.9 \pm 0.3$ & 36 & $1.0 \pm 0.1$ & 39 & $0.9 \pm 0.2$ & 53 \\
\hline Larval survival (\%) & $77.1 \pm 20.8^{a}$ & 36 & $77.8 \pm 19.4^{a}$ & 39 & $69.2 \pm 20.2^{\mathrm{a}}$ & 53 \\
\hline
\end{tabular}

'Distribution-free data were obtained, for which no statistical analysis was applied.

Means with different superscripts in the same row are significantly different $(P \leq 0.05)$.

female was also significantly higher in treatments $\mathrm{CON}$ and ART as compared with treatment FRE. In experiment 2, the spawn frequency was equal in treatments FRE and ART, but lower in treatment CON, while the total number of spawns and the number of females with repeat spawn performance were equal among treatments FRE and $\mathrm{CON}$, but higher in treatment ART. This difference was statistically significant for the number of females with two or more spawning events. Furthermore, in experiment 2 the number of eggs produced per female in treatment ART was significantly higher than in treatment FRE, but not significantly different from treatment CON. Fecundity, or the number of eggs released per spawning event, was not affected by dietary treatment in either experiment.

\section{Spermatophore quality}

In experiment 1 sperm count and spermatophore weight did not significantly differ among treatments. In experiment 2 these parameters were significantly higher in treatment ART than in the remaining treatments. Sperm counts were generally higher in experiment 1 than in experiment 2 .

\section{Offspring quality}

Offspring quality parameters were not affected by dietary treatment in any of the experiments. In general, the quality of the offspring produced in experiment 2 was higher than in experiment 1 .

\section{Discussion}

Mortality rates were high throughout both experiments, resulting in useful lifetime percentages below $50 \%$. It is known that adult shrimp are very sensitive to stress (Bray \& Lawrence 1992; Browdy 1992; Mosquera 1999). For example, Naessens et al. (1997) report 50\% mortality of wild L. vannamei during acclimation to culture conditions. However, in the present study, stress conditions were reduced to a minimum by improving transport from the beach to the hatchery facilities (shorter transport time, cooling of the transport tanks, placing the reproducers in small individual nets), careful handling and avoiding noise. From personal experience it seems that high mortality rates are almost inevitable with wild reproducers of the species $L$. vannamei. In agreement, high female mortalities are reported as a result of tank transfers and sourcing of L. vannamei (Galgani \& AQUACOP 1989; Naessens et al. 1997; Sangha et al. 1998) and other species (Menasveta et al. 1994; Cavalli et al. 1997). The only viable way to obtain sufficient research data in these conditions was to stock and monitor a large number of animals in the maturation tanks.

On average, $84 \%$ of the feeding regime in commercial facilities of the western hemisphere is based on fresh food 
items like squid, mussel, marine Polychaetes and others, while in Asia a total dependence on fresh food seems to be the rule (Wouters et al. 2000). The reason for this is that high replacement levels of fresh food with artificial diets reduce broodstock performance and offspring quality (Harrison 1990; Bray et al. 1990; Bray \& Lawrence 1992), because artificial diets do not meet the exact nutritional requirements of shrimp during the maturation process and because of the preferential ingestion of fresh food over artificial diet. The present study clearly suggests the feasibility of substituting $50 \%$ of the fresh food with artificial broodstock diets. This fresh food substitution did not affect the response variables negatively. On the contrary, spawn frequency doubled in experiment 1 (treatments CON and ART) and the production of eggs per female doubled in experiment 2 (treatment ART). In both experiments, repeat spawn performance was improved in the treatments fed the artificial diets, which means that spawner exhaustion - that typically occurs over time in captive broodstock animals - was overcome. Female performance was better in treatments receiving artificial diets than in the fresh food treatment, thus supporting the quality of our practical artificial diet. The development of the diet used in this study was based upon the information acquired from literature and analysis of existing commercial broodstock diets (Wouters et al. 2001), and a series of trial-and-error experiments. The present results confirm the findings of Nascimento et al. (1991) with Litopenaeus schmitti, that combining fresh food and artificial diets in a shrimp broodstock feeding regime is a better practice than relying on fresh food alone. Several abstracts have been published from studies that also evaluated a $50 \%$ fresh food substitution with dry diets: Verstraete et al. (1995) and Coutteau et al. (1998) with L. vannamei, and Denece et al. (1999) with Litopenaeus stylirostris. Verstraete et al. (1995) obtained an increased maturation frequency in tanks fed the dry diet, but a decrease in egg hatching percentage and spawning size. At the end, the production of nauplii per female remained unaffected by the partial fresh food replacement. Coutteau et al. (1998) obtained an improved survival rate, but an inferior production of nauplii per female. Denece et al. (1999) obtained similar reproductive performance and nauplii quality with dry diets $(50 \%)$ or fresh food. None of the previous studies reported results as positive as those obtained in the present study.

Fresh food substitution levels above $50 \%$ have not yet proven successful. In contrast, moist artificial diets or artificial diets containing minced fresh food have been used successfully for total fresh food substitution by Galgani $e t$ al.
(1989) and Galgani \& AQUACOP (1989) for L. stylirostris, $L$. vannamei and Fenneropenaeus indicus, and by Marsden et al. (1997) with Penaeus monodon. However, these diets have a short shelf-life and low water stability, limiting commercial application.

It is worth emphasizing the fact that the fresh food items that were substituted in the present commercial hatchery trial were precisely those that are presumed indispensable for normal maturation and reproduction, i.e. bloodworms and enriched Artemia biomass (Browdy 1992; Kawahigashi 1992; Naessens et al. 1997). In hatcheries of the western hemisphere, bloodworms constitute the most expensive broodstock diet ingredient (Rhodes et al. 1992; Kawahigashi 1992, 1998), and their replacement with dry diet is set as a priority by various authors (Harrison 1997).

In a preliminary study (Wouters 2001), it was found that incorporating freeze-dried Artemia biomass into an artificial broodstock diet increased diet ingestion, improved gonad maturation in female and male $L$. vannamei, and increased spawning and repeat spawning performance. This beneficial effect of Artemia meal was, however, more pronounced in pond reproducers than in wild reproducers. The present study looks further into the potential of Artemia meal as an ingredient in dry diets for wild reproducers. In experiment 1 , a positive effect of Artemia meal inclusion could not be confirmed. On the contrary, in experiment 2 the inclusion of freeze-dried Artemia to the artificial diet had various positive effects: more spawns, better repeat spawn performance, higher egg production per female, higher sperm counts and an increased spermatophore weight. These responses suggest that the beneficial effects of fresh-frozen Artemia biomass, as reported in Wouters et al. (1999) for the same reproductive parameters, are maintained after processing it into a meal and including it to an artificial diet.

The results of experiment 1 were sometimes different to those obtained in experiment 2 (the effect of fresh food substitution, the effect of Artemia meal inclusion, sperm counts, offspring quality). It is impossible to pinpoint one cause for these observed differences. Seasonal-environmental effects and geographical effects may have contributed to these differences (Hansford \& Marsden 1995; Marsden et al. 1997). Different maturation facilities and environmental conditions might also have contributed to the observed variation (Bray \& Lawrence 1992).

In conclusion, this study suggests the feasibility of substituting $50 \%$ of the classical fresh food regime with practical dry artificial diets in $L$. vannamei broodstock facilities. In this way, bloodworms and Artemia biomass 
may be deleted from the feeding regime. The use of Artemia meal appears to further improve the performance of the artificial diets.

\section{Acknowledgements}

Our sincere gratitude goes to David Garriques and Eloy Calderón of Granjas Marinas (El Rosario S.A) for allowing us to conduct research in their facilities and for providing invaluable assistance and advise. This work was supported by the VLIR-Own Initiative Program of the Flemish InterUniversity Council (VL.I.R). At the time of this study, Byron Zambrano was a student of the Universidad Técnica de Manabi (Ecuador) and Marcos Espin was a student of the Escuela Superior Politécnica del Litoral (Ecuador).

\section{References}

Alfaro, J. \& Lozano, X. (1993) Development and deterioration of spermatophores in pond-reared Penaeus vannamei. J. World Aquacult. Soc., 24, 522-529.

Bray, W.A. \& Lawrence, A.L. (1992) Reproduction of Penaeus species in captivity. In: Marine Shrimp Culture: Principles and Practices (Fast, A. \& Lester, L.J. eds), pp. 93-170. Elsevier. Science Publishers B.V., Amsterdam, The Netherlands.

Bray, W.A., Lawrence, A.L. \& Lester, L.J. (1990) Reproduction of eyestalk-ablated Penaeus stylirostris fed various levels of total dietary lipid. J. World Aquacult. Soc., 21, 41-52.

Browdy, C.L. (1992) A review of the reproductive biology of Penaeus species: perspectives on controlled shrimp maturation systems for high quality nauplii production. In: Proceedings of the Special Session on Shrimp Farming, World Aquaculture Society, Orlando, Florida, USA (Wyban, J. ed.), pp. 22-51. World Aquaculture Society, Baton Rouge, LA, USA

Browdy, C.L. (1998) Recent developments in penaeid broodstock and seed production technologies; improving the outlook for superior captive stocks. Aquaculture, 164, 3-21.

Browdy, C.L., Hadani, A., Samocha, T.M. \& Loya, Y. (1989) An evaluation of frozen Artemia as a dietary supplement for the stimulation of reproduction in penaeid shrimp. In: Aquaculture - $A$ Biotechnology in Progress (De Pauw, N., Jaspers, E., Ackefors, H. \& Wilkins, N. eds), pp. 617-623. European Aquaculture Society, Bredene, Belgium.

Cahu, C.L., Cuzan, G. \& Quazuguel, P. (1995) Effect of highly unsaturated fatty acids, K-tocopherol and ascorbic acid in broodstock diet on egg composition and development of Penaeus indicus. Comp. Biochem. Physiol., 112, 417-424.

Cavalli, R.O., Scardua, M.P. \& Wasielesky, W.J. (1997) Reproductive performance of different sized wild and pond-reared Penaeus paulensis females. J. World Aquacult. Soc., 28, 260-267.

Chang, P.-S., Chen, L.-J. \& Wang, Y.-C. (1998) The effect of ultraviolet irradiation, heat, $\mathrm{pH}$, ozone, salinity and chemical disinfectants on the infectivity of white spot syndrome baculovirus. Aquaculture, 166, 1-17.

Coutteau, P., Pinon, E. \& Balcazar, Y. (1998) Effect of a commercial maturation diet on broodstock performance of Penaeus vannamei in a commercial Hatchery (Abstract). Ist Latin American Shrimp Culture Congress and Exhibition, Panama City, Panama.
Denece, E., Pham, D. \& Coutteau, P. (1999) Reproductive response of Penaeus stylirostris to a $50 \%$ substitution of fresh food by a new shrimp maturation feed. In: Book of Abstracts, Aquaculture '99. Sydney, Australia, pp. 601. World Aquaculture Society, Baton Rouge, LA, USA.

Flegel, T. (2001) Shrimp head meal - does it spread disease? Asian Aquaculture Magazine, July/August, 30-31.

Galgani, M.L. \& AQUACOP (Goguenheim, J., Galgani, F. \& Cuzon, G.) (1989) Influence du régime alimentaire sur la reproduction en captivité de Penaeus vannamei and Penaeus stylirostris. Aquaculture, 80, 97-109.

Galgani, M.L., Cuzon, G., Galgani, F. \& Goguenheim, J. (1989) Influence du régime alimentaire sur la reproduction en captivité de Penaeus indicus. Aquaculture, 81, 337-350.

Hansford, S. \& Marsden, G. (1995) Temporal variation in egg and larval productivity of Penaeus monodon eyestalk ablated spawners. J. World Aquacult. Soc., 26, 396-405.

Harper, J.M. (1988) Effects of extrusion processing on nutrients. In Nutritional Evaluation of Food Processing (Karmas, E. \& Harris, R.S. eds), pp. 365-391 Van Nostrand Reinhold, New York, 786 pp.

Harrison, K.E. (1990) The role of nutrition in maturation, reproduction and embryonic development of decapod crustaceans: a review. J. Shellfish Res., 9, 1-28.

Harrison, K.E. (1997) Broodstock nutrition and maturation diets. In: Crustacean Nutrition, Advances in World Aquaculture (D'A bramo, L.R., Conklin, D.E. \& Akiyama, D.M. eds), vol. 6, pp. 390-408. The World Aquaculture Society, Baton Rouge, LA, USA.

Kawahigashi, D.K. (1992) A survey of commercial maturation technology in the Western hemisphere. In: Proceedings of the Special Session on Shrimp Farming, World Aquaculture Society, Orlando, Florida (Wyban, J. ed.), pp. 52-54. World Aquaculture Society, Baton Rouge, LA, USA.

Lavens, P. \& Sorgeloos, P. (1996) Manual on the Production and Use of Live Food for Aquaculture. FAO technical paper 361. Laboratory of Aquaculture \& Artemia Reference Center, Ghent University, Gent, Belgium.

Marsden, G.E., McGuren, J.J. \& Hansford, S.W. (1997) A mois artificial diet for prawn broodstock: its effect on the variable reproductive performance of wild caught Penaeus monodon. Aquaculture, 149, 145-156.

Mead, R., Curnow, R.N. \& Hasted, A.M. (1993) Statistical Methods in Agriculture and Experimental Biology. Chapman \& Hall, London, UK.

Menasveta, P., Sangpradub, S. \& Piyatiratitivorakul, S. (1994) Effects of broodstock size and source on ovarian maturation and spawning of Penaeus monodon Fabricius from the Gulf of Thailand. J. World Aquacult. Soc., 25, 41-49.

Mosquera, G. (1999) La pesquería artesanal de reproductores de camarón: Estado actual y sus perspectivas. In: Principios $Y$ Criterios Técnicos Para El Desarrollo Sustentable de la Pesqueria de Reproductores de Camarón (Rosero, J.Z. \& Burgos, M. eds), pp. 1-31. Informe técnico del Instituto Nacional de Pesca y el Programa de Manejo de Recursos Costeros, Guayaquil, Ecuador. Naessens, E., Lavens, P., Gómez, L., Browdy, C., McGovernHopkins, K., Spencer, A., Kawahigashi, D. \& Sorgeloos, P. (1997) Maturation performance of Penaeus vannamei co-fed Artemia biomass preparations. Aquaculture, 155, 87-101.

Nascimento, I.A., Bray, W.A., Leung-Trujillo, J.R. \& Lawrence, A.L. (1991) Reproduction of ablated and unablated Penaeus schmitti. Captivity using diets consisting of fresh-frozen natural and dried formulated feeds. Aquaculture, 99, 387-398.

Pinon, E. (2000) Producing ragworms for shrimp broodstock maturation. Global Aquaculture Advocate, 3, 82-84. 
Rhodes, R.J., McGovern-Hopkins, K. \& Browdy, C.L. (1992) Preliminary financial feasibility analysis of an independent marine shrimp hatchery located in South Carolina. S.C. Marine Resources Division Technical Report no. 80, 11 pp. South Carolina Wildlife and Marine Resources Department. Charleston, SC, USA.

Robertson, L., Bray, W. \& Lawrence, A. (1991) Reproductive response of Penaeus stylirostris to temperature manipulation. J. World Aquacul. Soc., 22, 109-117.

Sangha, R.S., Chavez-Sanchez, M.C., Martinez-Palacios, C.A. \& Martinez-Rodriguez, I.E. (1998) Supplementing L-Ascorbic-2Polyphosphate in Broodstock Diet of Penaeus (Litopenaeus) Vannamei at a hatchery. In: Book of Abstracts, Aquaculture '98 Conference of the World Aquaculture Society, pp. 672, Bally's, Las Vegas, Nevada, USA

Simon, C.M. (1982) Large-scale, commercial application of penaeid shrimp maturation technology. J. World Maricul. Soc., 13, 301-312.

Verstraete, P., De La Mora, B. \& Lavens, P. (1995) Maturation of Penaeus vannamei by using dry pellets as a partial substitute of the natural diet. In: Larvi'95 (Lavens, P., Jaspers, E. \& Roelants, I. eds), Special Publication 24, pp. 76-78, European Aquaculture Society, Gent.
Wouters, R. (2001) Importance of broodstock nutrition in White shrimp Litopenaeus vannamei. Thesis submitted in fulfillment of the requirements for the degree of Doctor (PhD), $195 \mathrm{pp}$. Faculty of Agricultural and Applied Biological Sciences. Ghent University, Gent.

Wouters, R., Gómez, L., Lavens, P. \& Calderón, J. (1999) Feeding enriched Artemia biomass to Penaeus vannamei broodstock: Its effect on reproductive performance and larval quality. J. Shellfish Res., 18, 651-656.

Wouters, R., Nieto, J. \& Sorgeloos, P. (2000) Artificial diets for penaeid shrimp. Global Aquaculture Advocate, 3, 61-62.

Wouters, R., Nieto, J. \& Sorgeloos, P. (2001) Penaeid shrimp broodstock nutrition: an updated review on research and development. Aquaculture, 202, 1-21.

Wyban, J., Martinez, G. \& Sweeney, J. (1997) Adding paprika to Penaeus vannamei maturation diet improves nauplii quality. World Aquacult., 28, 59-62.

Xu, X.L., Ji, W.L., Castell, J.D. \& O’Dor, R.K. (1994) Influence of dietary lipid sources on fecundity, egg hatchability and fatty acid composition of Chinese prawn (Penaeus chinensis) broodstock. Aquaculture, 119, 359-370. 